\title{
Back-tracking water vapour contributing to a precipitation event over Trentino: a case study
}

\author{
Alessio BERTò*1 $^{*}$, Andrea BuZZI ${ }^{2}$ and Dino ZARDi ${ }^{1}$ \\ ${ }^{1}$ Dipartimento di Ingegneria Civile ed Ambientale Università di Trento, Trento, Italy \\ ${ }^{2}$ Institute of Atmospheric Sciences and Climate, Bologna, Italy
}

(Manuscript received August 8, 2003; in revised form March 16, 2004; accepted March 16, 2004)

\begin{abstract}
The relation between individual precipitation patterns over an Alpine target area and the origin of the water vapour which contributes to them is investigated. Back-trajectories are calculated, starting from selected ending points over the target area, by means of the Lagrangian model FLEXTRA, on the basis of meteorological fields provided by ECMWF 4d-Var analysis data. Suitable clustering procedure is devised to identify representative flow patterns from calculated trajectories. The procedure is applied to a recent precipitation event (24-27 November 2002) adopted as a test case. The analysis allows to identify the contribution of various air streams to the precipitation, as well as the regions where most of the evaporation into the air streams occurred at various phases of the event.
\end{abstract}

\section{Zusammenfassung}

Die Beziehungen zwischen Niederschlagsmustern in einer speziell betrachteten Region in den Alpen und dem Ursprung des zum Niederschlag beitragenden Wasserdampfs werden untersucht. Ausgehend von ECMWF Analysefeldern werden Rückwärtstrajektorien von ausgewählten Endpunkten über der betrachteten Region durch das Lagrange'sche Modell FLEXTRA berechnet. Eine geeignete Clustering-Methode wird vorgestellt, um in den berechneten Rückwärtstrajektorien Strömungsmuster identifizieren zu können. Die Methode wird an einer Niederschlagsepisode (24-27 November 2002) exemplarisch angewendet, und soll als Testfall dienen. Die Analyse gestattet, Beiträge zum Niederschlag zu identifizieren, die von verschiedenen Luftströmen herrühren. Außerdem liefert sie für die verschiedenen Phasen der Episode die Regionen, über denen die größte Verdunstung in die Luftströme hinein geschah.

\section{Introduction}

Strong precipitation events are the source of most natural hazards in the Alpine area. These events may display a wide range of patterns depending on various factors affecting the processes which transport moist air masses and lift them over the Alps. In the case of synoptic scale cyclonic flows, the orography enhances precipitation upstream, and in general induces a drying effect downstream of the mountains. However strong precipitation can occur even downstream when conditions are favourable for developments of convection.

The Alps affect atmospheric dynamics on a broad range of scales, the most relevant ones ranging from the meso- $\alpha$ (e.g. lee cyclogenesis and modification of upper level troughs, TIBALDI et al., 1990), through meso$\beta$ (e.g. modification of fronts by orography, HoINKA et al., 1990; BUZZI and ALBERONI, 1992) up to the meso- $\gamma$ (e.g. circulations in individual valleys and inside individual clouds). Recent studies, especially those developed in connection with the Mesoscale Alpine Programe (Bougeault et al., 2001), have focused

\footnotetext{
*Corresponding author: Alessio Bertò, Dipartimento di Ingegneria Civile ed Ambientale, Università di Trento, Via Mesiano 77, 38050 Trento, Italy, e-mail: alessio.berto@ing.unitn.it
}

on the synoptic-scale situations which are most likely to produce severe precipitation events in the southern Alpine region. The physical mechanism of orographic precipitation has been deeply explored (see, for example, BuzZi et al., 2003; GHeusi and Stein, 2002; Medina and Houze, 2003; RotunNo and FerRetTI, 2000; RotunNo and FERRETTi, 2003). However, in many cases the peculiar influence of local orography is still to be investigated. This is the case of Trentino (Fig. 1), which stretches out as a wedge from the main Alpine area into the Po Plain. Moreover, little is known at present about the relationship between detectable local and regional flow structures and the larger scale processes determining the moisture fluxes at lower levels and the water vapour transport and evolution at upper levels. A deeper analysis of mesoscale dynamical features of remarkable events along with the diagnosis of heat and moisture budgets would improve conceptual models of the orographic influence on precipitation. To this purpose a remarkable input can be provided by the reconstruction of the history of water vapour precipitating over the investigated target areas. Isotopic composition of water can be used as a suitable tracer to detect the origin of precipitating water. Indeed measurements of 